\title{
A tricky late occurrence of Bochdalek's hernia
}

\author{
Petros Charalampoudis, Ioannis D Kostakis, Chrysoula Doula, Dimitrios Mantas
}

Athens University School of Medicine, Athens, Greece

\section{Correspondence to} Petros Charalampoudis, pcharalampoudis.laiko@gmail. com

Accepted 26 February 2015

\section{DESCRIPTION}

A 32-year-old man with unremarkable medical history was urgently admitted with acute hypogastric pain of $24 \mathrm{~h}$ onset. On presentation he was apyrexial. Clinical examination revealed low abdominal tenderness with moderate rebound; bowel sounds were normal. The patient reported undisturbed stool and flatus passage; digital rectal examination revealed the presence of stool in the rectum without any tenderness or blood. Complete blood count showed a marked leukocytosis of $18610 / \mu \mathrm{L}$ with an elevated neutrophilic differential (92.4\%). Plain chest (figure 1, white arrow) and

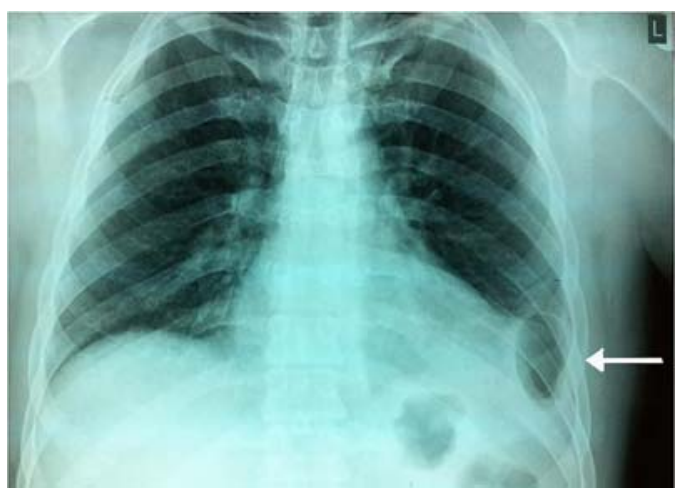

Figure 1 Plain chest film (white arrow) showing a colonic loop abnormally positioned into the left hemithorax.

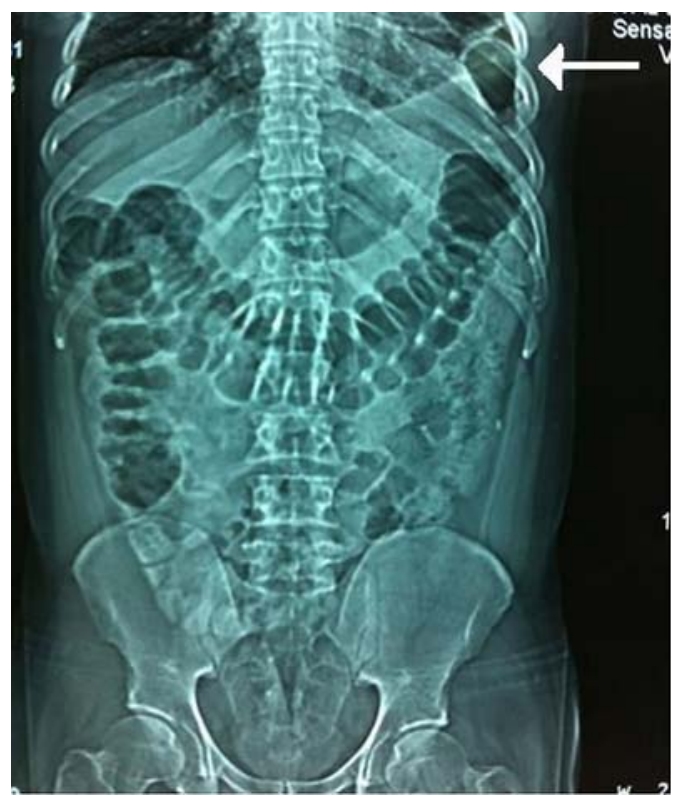

Figure 2 Plain abdominal film (white arrow) depicting the intrathoracic colonic loop.

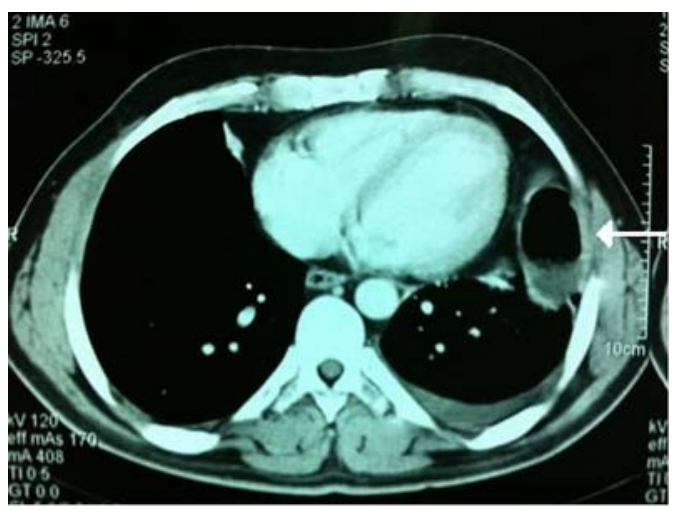

Figure 3 Chest CT scan (white arrow) showing the intrathoracic colonic loop.

abdominal (figure 2, white arrow) films showed the presence of bowel above the level of the left hemidiaphragm, whereas abdominal ultrasound was unremarkable. Chest and abdomen CT scans demonstrated a colonic loop in the left hemithorax (figure 3, white arrow).

On exploratory laparotomy, a Bochdalek's hernia containing the left colonic flexure was revealed. The herniated colon was repositioned in the abdominal cavity and the defect was closed with running absorbable suture. The postoperative course was uneventful and the patient was discharged on the fourth postoperative day having resumed normal bowel function.

\section{Learning points}

Bochdalek's hernia is a form of congenital diaphragmatic hernia along the posterior diaphragm in the space between the pars lumbaris and the pars costalis. ${ }^{1}$ Peritoneal fat and/or solid or hollow abdominal organs enter the thorax through this diaphragmatic defect.

- It usually manifests during infancy, mostly with respiratory distress, and it is left sided in most cases $(80 \%)$. Adult patients are usually asymptomatic and are incidentally diagnosed. ${ }^{1-3}$ Bochdalek's hernia occasionally manifests with bowel obstruction. ${ }^{1}$

- In our case, lower abdominal pain was an unexpected symptom given the definitive diagnosis of a diaphragmatic hernia. In cases of intractable abdominal pain, differential diagnosis should include remote sites of gastrointestinal pathology.

Twitter Follow Dimitrios Mantas at @dvmantas 
Contributors $\mathrm{DM}$ and $\mathrm{PC}$ performed the operation and equally contributed to manuscript preparation. IDK and CD assisted at the operation and looked after the patient postoperatively.

Competing interests None.

Patient consent Obtained.

Provenance and peer review Not commissioned; externally peer reviewed.

\section{REFERENCES}

1 Sandstrom CK, Stern EJ. Diaphragmatic hernias: a spectrum of radiographic appearances. Curr Probl Diagn Radiol 2011;40:95-115.

2 Eren S, Ciris F. Diaphragmatic hernia: diagnostic approaches with review of the literature. Eur J Radiol 2005;54:448-59.

3 Garofano-Jerez JM, Lopez-Gonzalez Jde D, Valero-Gonzalez MA, et al. Posterolateral Bochdalek diaphragmatic hernia in adults. Rev Esp Enferm Dig 2011;103:484-91.

Copyright 2015 BMJ Publishing Group. All rights reserved. For permission to reuse any of this content visit http://group.bmj.com/group/rights-licensing/permissions.

BMJ Case Report Fellows may re-use this article for personal use and teaching without any further permission.

Become a Fellow of BMJ Case Reports today and you can:

- Submit as many cases as you like

- Enjoy fast sympathetic peer review and rapid publication of accepted articles

- Access all the published articles

- Re-use any of the published material for personal use and teaching without further permission

For information on Institutional Fellowships contact consortiasales@bmjgroup.com

Visit casereports.bmj.com for more articles like this and to become a Fellow 